\title{
A STUDY TO ASSESS THE KNOWLEDGE AND ATTITUDE OF SCHOOL TEACHERS REGARDING LEARNING DISABILITIES AMONG CHILDREN IN SELECTED SCHOOLS AT CHURU.
}

\author{
Mr. Shakti Singh Soni \\ [Ph.D. Nursing Scholar] \\ Assistant Professor cum H.O.D. Psychiatric [Mental Health Nursing] \\ S.N. College of Nursing Sri Ganganagar \\ Corresponding Email- dr.ssoni0201@gmail.com
}

\begin{abstract}
Introduction: Today's children are tomorrow's citizens. They are in a continuous process of growth and development. Any alteration in its course leads on to developmental disorders. The developmental disorders learning disability plays a significant role as a silent handicap among children. It is estimated that $4-5 \%$ of students in school have learning disability.

Methods \& Material: A descriptive research design was adapted to conduct the study. Target population was primary school teachers in Churu District. A structured questionnaire for knowledge and attitude scale for attitude assessment was used. 120 samples were selected from the target population by convenient sampling. Data was collected and analyzed using mean, median, percentage, SD, Chi square and Coefficient correlation and presented in the form of tables and diagrams.

Results: The study revealed that major portion (35\%) of primary school teachers belonged to the age group 30-35 and of these $93 \%$ were females. Majority of them (75\%) possessed B.Ed degree. Nearly half of them (48.33) had less than 5 years of teaching experience.91.67\% studied child psychology in their curriculum but very few (8\%) had opportunity to attend in service educations on problems of learning. No teachers had opportunity to teach such children. Chi square revealed a significant association $(\mathrm{P}<0.05)$ between knowledge and Educational qualification. Significant association was identified between attitude and age of the subjects also.

Interpretation and Conclusion: A positive correlation was identified between knowledge and attitude score of teachers on the subject. The study concluded that need for providing knowledge on learning disability is an important strategy to utilize teachers as effective contributors towards child mental health services.
\end{abstract}

Keywords - Leaning disability, Attitude, Knowledge, Disabled Children, School teacher 


\section{INTRODUCTION}

According to Mahatma Gandhi,

'Education means an all round drawing out of the best in child and men - body, mind and spirit" an understanding teacher can identify the capacities, strength, and weakness innate in each student.

Jones Elizabeth Pryce states that children are at school for a large part of their vital time for the emotional and physical development. School provides a setting for the development of friendship, socialization and for the introduction and reinforcement of behavior ${ }^{2}$. Change of behavior in the desired direction is termed as learning. Learning is a very complex brain function of understanding, recalling, and utilization of this knowledge in the future. The capacity to learn varies from individual to individual - even among children of the same age and intellectual ability.

\section{METHODOLOGY}

The research approach used for the study is descriptive in nature.

Research Approach: The research approach used for the study is descriptive in nature.

Research Design: The study is designed in the form of non experimental descriptive type.

\section{Sample and Sampling technique:}

The sample for the present study will be comprised of 120 primary school teachers selected by Convenient sampling technique from selected schools at Churu. Convenient sampling is a strategy in which the researcher's knowledge of the population and its elements are used to select samples which are typical of the population

\section{Data Collection:}

Structured Questionnaire for Knowledge Assessment Rating scale for attitude measurement.

\section{RESULTS}

This chapter deals with the analysis and interpretation of the data collected from sixty school teachers from selected schools in churu district regarding their knowledge and attitude towards Learning Disabilities among children.

Kerlinger (1976) has defined analysis as "the categorizing, manipulating and summarizing of data to obtain answers to research hypothesis question"3.

Abdellah and Levine mentioned that interpretation of tabulated data can bring light to the real meaning of the findings ${ }^{4}$. The data were collected through structured questionnaire and entered in 
master sheet. The obtained data was analyzed by using descriptive statistics, which were necessary to describe Socio demographic variables, the knowledge and attitude level, and the relationship between the selected demographic variables and knowledge and attitude ${ }^{5}$.

\section{Objectives of the study}

1. To assess the level of knowledge of teachers regarding learning disabilities among children

2. To measure the attitude of teachers towards children with learning disabilities.

3. To associate the knowledge of teachers with selected socio demographic variables.

4. To associate the attitude of teachers with socio demographic variables.

5. To correlate the knowledge and attitude of school teachers regarding learning disability.

\section{SECTION I}

DESCRIPTION OF STUDY SUBJECTS BY SOCIODEMOGRAPHIC VARIABL ES

In this section the researcher analyzed and categorized the subjects of study into various groups based on the socio demographic variables.

Table 1 : Frequency and Percentage distribution of subjects according to age in years $N=120$

\begin{tabular}{|c|c|c|c|}
\hline S.n. & Variables & $\begin{array}{l}\text { Frequ } \\
\text { ency }\end{array}$ & $\begin{array}{l}\text { Percentage } \\
(\%)\end{array}$ \\
\hline \multicolumn{4}{|c|}{ Age in years } \\
\hline 1. & $25-29$ & 32 & 26.67 \\
\hline 2. & $30-34$ & 42 & 35 \\
\hline 3. & $35-39$ & 28 & 23.33 \\
\hline \multirow[t]{2}{*}{4.} & $\geq 40$ & 18 & 15 \\
\hline & Gender & & \\
\hline 1. & Male & 8 & 6.67 \\
\hline \multirow{2}{*}{2.} & Female & 112 & 93.33 \\
\hline & $\begin{array}{l}\text { Educational } \\
\text { Qualification }\end{array}$ & & \\
\hline 1. & $\begin{array}{l}\text { Teacher's Training } \\
\text { Programme }\end{array}$ & 6 & 5 \\
\hline 2. & BED & 92 & 76.67 \\
\hline 3. & M. Ed & 4 & 3.33 \\
\hline \multirow[t]{2}{*}{4.} & Others & 18 & 15 \\
\hline & Years of Experience & & \\
\hline 1. & $0-5$ & 58 & 48.33 \\
\hline 2. & $6-10$ & 38 & 31.67 \\
\hline 3. & $11-15$ & 20 & 16.67 \\
\hline \multirow[t]{2}{*}{4.} & $\geq 16$ & 4 & 3.33 \\
\hline & Marital Status & & \\
\hline 1. & Married & 104 & 86.67 \\
\hline \multirow[t]{2}{*}{2.} & Unmarried & 14 & 11.67 \\
\hline & $\begin{array}{l}\text { Child } \\
\text { Psycholo } \\
\text { gy }\end{array}$ & & \\
\hline 1. & $\begin{array}{l}\text { Studied Child } \\
\text { Psychology }\end{array}$ & 110 & 91.67 \\
\hline \multirow[t]{2}{*}{2.} & $\begin{array}{l}\text { Not Studied Child } \\
\text { Psychology }\end{array}$ & 10 & 8.33 \\
\hline & \begin{tabular}{l}
\multicolumn{1}{c}{ In } \\
service \\
Education
\end{tabular} & & \\
\hline 1. & $\begin{array}{l}\text { Attended In service } \\
\text { Education }\end{array}$ & 110 & 91.67 \\
\hline \multirow[t]{2}{*}{2.} & $\begin{array}{l}\text { Not Attended In service } \\
\text { Education }\end{array}$ & 10 & 8.33 \\
\hline & $\begin{array}{l}\text { Teaching children with } \\
\text { Learning Disability }\end{array}$ & & \\
\hline 1. & $\begin{array}{l}\text { Taught children with } \\
\text { Learning Disability }\end{array}$ & 0 & 0 \\
\hline 2. & $\begin{array}{l}\text { Not Taught } \\
\text { children with } \\
\text { Learning } \\
\text { Disability }\end{array}$ & 120 & 100 \\
\hline
\end{tabular}


Table 1 shows the distribution of teachers based on their age, Gender, Educational Qualification, Years of Experience, Marital Status, Child Psychology, In service Education, Teaching children with Learning Disability.

\section{SECTION II}

\section{RELATIONSHIP BETWEEN THE} SELECTED SOCIO

\section{DEMOGRAPHIC}

VARIABLES

\section{WITH THE KNOWLEDGE SCORES}

Association between the knowledge of school teachers regarding Learning Disability and the base line characteristics such as age, gender, marital status, educational qualification, years of experience Child Psychology in the curriculum, In-service education, and Experience in teaching children with learning disability received. In order to determine the significance of the relationship, chi - square and Fisher's Exact Test were used. Teachers were divided into two groups based on the knowledge score. Those who scored the below or equal to the median score (20) and those who scored above the median score (20).

Table 2 Statistical Inference based on Chi Square test between above and below median of knowledge score of the subjects based on each demographic variable.

\begin{tabular}{|c|c|c|c|c|c|c|}
\hline $\mathbf{S}$ & $\begin{array}{l}\text { Socio } \\
\text { demographic } \\
\text { variables }\end{array}$ & $\begin{array}{l}\text { Frequency } \\
\text { of subjects } \\
\leq \text { median } \\
\text { value(20) }\end{array}$ & $\begin{array}{l}\text { Frequency } \\
\text { of subjects } \\
>\text { median } \\
\text { value }(20)\end{array}$ & $\begin{array}{l}\text { Total } \\
\text { Frequency }\end{array}$ & $\begin{array}{l}\text { Chi } \\
\text { Square }\end{array}$ & Result \\
\hline 1 & $\begin{array}{l}\text { Age in Years } \\
\leq 34 \text { years } \\
>34 \text { years }\end{array}$ & $\begin{array}{l}36 \\
18\end{array}$ & $\begin{array}{l}38 \\
30\end{array}$ & $\begin{array}{l}74 \\
46\end{array}$ & 0.752 & $\begin{array}{l}\text { Not } \\
\text { signifi } \\
\text { cant }\end{array}$ \\
\hline 2 & \begin{tabular}{|l} 
Gender \\
Male \\
Female
\end{tabular} & $\begin{array}{l}4 \\
52\end{array}$ & $\begin{array}{l}4 \\
60\end{array}$ & $\begin{array}{l}8 \\
112\end{array}$ & $0.641^{*}$ & $\begin{array}{l}\text { Not } \\
\text { Signifi } \\
\text { cant }\end{array}$ \\
\hline 4 & $\begin{array}{l}\text { Education } \\
\text { Qualification } \\
\text { B.Ed\&M.Ed } \\
\text { Others }\end{array}$ & $\begin{array}{l}36 \\
20\end{array}$ & $\begin{array}{l}58 \\
4\end{array}$ & $\begin{array}{l}96 \\
24\end{array}$ & $0.042 *$ & Significant \\
\hline 5 & $\begin{array}{l}\text { Years of } \\
\text { Experienc } \\
\text { e } \\
\leq 10 \text { Years } \\
>10 \text { Years }\end{array}$ & $\begin{array}{l}38 \\
10\end{array}$ & $\begin{array}{l}27 \\
5\end{array}$ & $\begin{array}{l}45 \\
15\end{array}$ & 3.214 & $\begin{array}{l}\text { Not } \\
\text { signifi } \\
\text { cant }\end{array}$ \\
\hline 6 & $\begin{array}{l}\text { Marital Status } \\
\text { Married } \\
\text { Others }\end{array}$ & $\begin{array}{l}48 \\
8\end{array}$ & $\begin{array}{l}56 \\
8\end{array}$ & $\begin{array}{l}104 \\
16\end{array}$ & $0.576^{*}$ & $\begin{array}{l}\text { Not } \\
\text { signifi } \\
\text { cant }\end{array}$ \\
\hline 7 & $\begin{array}{l}\text { Studied Child } \\
\text { Psychology } \\
\text { Not studied } \\
\text { Child } \\
\text { Psychology }\end{array}$ & $\begin{array}{l}64 \\
10\end{array}$ & $\begin{array}{l}46 \\
0\end{array}$ & $\begin{array}{l}110 \\
10\end{array}$ & $0.798^{*}$ & $\begin{array}{l}\text { Not } \\
\text { Signifi } \\
\text { cant }\end{array}$ \\
\hline 8 & $\begin{array}{l}\text { Attended } \\
\text { In service } \\
\text { Education } \\
\\
\text { Not Attended } \\
\text { Inservice } \\
\text { Education }\end{array}$ & 0 & 10 & $\begin{array}{l}10 \\
\\
110\end{array}$ & * & $\begin{array}{l}\text { Not } \\
\text { Signifi } \\
\text { cant }\end{array}$ \\
\hline
\end{tabular}

* Fisher's Exact Test Significant at 5\% level $(\mathrm{P}<0.05)$

Table 2 presents the substantive summary of Chi- square analysis, which was used to bring out the relationship between 
knowledge of teachers on learning disability and socio demographic variables.

\section{SECTION III}

Relationship between the Selected Socio - Demographic Variables with the Attitude Scores

In this section, the researcher brings out the association between the attitude of school teachers regarding Learning Disability and the base line characteristics such as age, gender, marital status, educational qualification, years of experience, Child Psychology in the curriculum and In service education. In order to determine the significance of the relationship, Chi - square and Fisher's Exact Test were used. The teachers were categorized into two groups based on the median attitude score (80.5) on Learning Disability, namely those who were below or equal to median score and those who were above the median score.

Table 3 Statistical Inference based on

Chi Square test between above and below median of Attitude score of the subjects based on each demographic variables.

\begin{tabular}{|c|c|c|c|c|c|c|}
\hline $\begin{array}{l}\mathrm{S} \\
\dot{\mathrm{N}} \\
\mathrm{o}\end{array}$ & $\begin{array}{l}\text { Socio } \\
\text { demographi } \\
\text { c variables }\end{array}$ & $\begin{array}{l}\text { Frequenc } \\
\text { y } \\
\text { ofsubject } \\
\text { s } \\
\leq \text { median } \\
\text { value( } 80 \text {. } \\
\text { 5) }\end{array}$ & 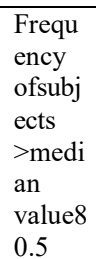 & Total & $\begin{array}{l}\text { Chi } \\
\text { Square }\end{array}$ & Results \\
\hline 1 & $\begin{array}{l}\text { Age } \\
\leq 34 \text { years } \\
>34 \text { years }\end{array}$ & $\begin{array}{l}44 \\
14\end{array}$ & $\begin{array}{l}30 \\
32\end{array}$ & $\begin{array}{l}74 \\
46\end{array}$ & 4.87 & significant \\
\hline 2 & $\begin{array}{l}\text { Gender } \\
\text { Male } \\
\text { Female }\end{array}$ & $\begin{array}{l}4 \\
54\end{array}$ & $\begin{array}{r}4 \\
58\end{array}$ & $\begin{array}{l}8 \\
112\end{array}$ & $0.66^{*}$ & $\begin{array}{l}\text { Not } \\
\text { significant }\end{array}$ \\
\hline 4 & $\begin{array}{l}\text { Educational } \\
\text { qualification } \\
\text { BEd\& MEd } \\
\text { Others }\end{array}$ & $\begin{array}{l}44 \\
16\end{array}$ & $\begin{array}{l}52 \\
8\end{array}$ & $\begin{array}{l}96 \\
24\end{array}$ & $0.27^{*}$ & $\begin{array}{l}\text { Not } \\
\text { significant }\end{array}$ \\
\hline 5 & $\begin{array}{l}\text { Years of } \\
\text { Experienc } \\
\text { e } \\
\leq 10 \text { years } \\
>10 \text { years }\end{array}$ & $\begin{array}{l}44 \\
14\end{array}$ & $\begin{array}{l}46 \\
16\end{array}$ & $\begin{array}{l}90 \\
30\end{array}$ & 0.02 & $\begin{array}{l}\text { Not } \\
\text { significant }\end{array}$ \\
\hline 6 & $\begin{array}{l}\text { Marital status } \\
\text { Married } \\
\text { Others }\end{array}$ & $\begin{array}{l}58 \\
8\end{array}$ & $\begin{array}{l}46 \\
8\end{array}$ & $\begin{array}{l}104 \\
16\end{array}$ & $0.52^{*}$ & $\begin{array}{l}\text { Not } \\
\text { significant }\end{array}$ \\
\hline 7 & $\begin{array}{l}\text { Learned Child } \\
\text { Psychology } \\
\text { Not learned } \\
\text { Child } \\
\text { Psychology }\end{array}$ & $\begin{array}{l}52 \\
6\end{array}$ & $\begin{array}{l}58 \\
4\end{array}$ & $\begin{array}{l}110 \\
10\end{array}$ & $0.46^{*}$ & $\begin{array}{l}\text { Not } \\
\text { significant }\end{array}$ \\
\hline 8 & $\begin{array}{l}\text { Attended } \\
\text { In-service } \\
\text { education } \\
\text { Not } \\
\text { attended In- } \\
\text { service } \\
\text { education }\end{array}$ & $\begin{array}{l}2 \\
56\end{array}$ & $\begin{array}{l}8 \\
54\end{array}$ & $\begin{array}{l}10 \\
110\end{array}$ & $0.36^{*}$ & $\begin{array}{l}\text { Not } \\
\text { significant }\end{array}$ \\
\hline
\end{tabular}

* Fisher's Exact Test Significance at $\mathrm{P}<0.05$

Table 3 shows analysis used to bring out the association between attitude of school teachers towards learning disabled children and socio demographic variables. Chi square test and Fisher's Exact Test (where sample size is less than five), were used to calculate the significance in the association between 
attitude and socio demographic variables.

\section{SECTION IV}

\section{LEVEL OF KNOWLEDGE OF THE}

\section{SUBJECTS}

In section IV, researcher analyzed the knowledge level of teachers regarding learning disability. Teachers were divided into three groups based on the knowledge score. Those who scored above $75 \%$ of the total score were considered as good knowledge, $50-75 \%$ as average and below 50\% as poor knowledge. Mean, Mean Percentage score and SD were estimated. The knowledge level of teachers on various aspects of the topic is estimated by dividing the questions into 6 areas, Meaning, Incidence, Cause, and Clinical features Diagnosis and Management. Mean percentage score and Standard deviation were calculated.

\section{Table 4}

Frequency and Percentage distribution of teachers according to the knowledge score on learning Disability

Good knowledge->75\%

Average knowledge - 50-75\%

Poor knowledge- $<\mathbf{5 0 \%}$

\begin{tabular}{|l|l|l|l|l|l|l|}
\hline $\begin{array}{l}\text { S. } \\
\text { No. }\end{array}$ & $\begin{array}{l}\text { Level of } \\
\text { knowledge }\end{array}$ & Frequency & $\begin{array}{l}\text { Percentage } \\
(\%)\end{array}$ & $\begin{array}{l}\text { Mea } \\
n \\
\text { score }\end{array}$ & $\begin{array}{l}\text { Mean } \\
\text { percentage } \\
\text { score(\%) }\end{array}$ & SD \\
\hline 1 & Good & 0 & 0 & 0 & 0 & 0 \\
\hline 2 & Average & 70 & 58.33 & 24.6 & 61.5 & 2.8 \\
\hline 3 & Poor & 50 & 41.67 & 16.16 & 40.4 & 2.2 \\
\hline
\end{tabular}

Table 4 indicates that, majority of teachers (58.33\%) had average knowledge on learning disability. Out of 120 samples, $50 \quad(41.67 \%)$ had poor knowledge regarding learning disability. No teachers possessed good knowledge on the subject. Mean score obtained for average knowledge level was 24.6 and mean percentage score $61.5 \%$ with a SD 2.8. For poor knowledge level, mean score was 16.6 and mean percentage score $40.4 \%$ with SD 2.2 .

Table 5 Mean and SD distribution of knowledge score on various areas of learning disability

\begin{tabular}{|l|l|c|l|l|l|l|}
\hline S. No & $\begin{array}{l}\text { Areas of } \\
\text { knowledge }\end{array}$ & $\begin{array}{l}\text { Maximum } \\
\text { score }\end{array}$ & $\begin{array}{l}\text { Range of } \\
\text { Score }\end{array}$ & $\begin{array}{l}\text { Mean } \\
\text { score }\end{array}$ & $\begin{array}{l}\text { Mean } \\
\text { oPercentag } \\
\text { e score }\end{array}$ & SD \\
\hline 1 & Meaning & 9 & $0-7$ & $\begin{array}{l}3.4 \\
5\end{array}$ & 38.33 & 1.98 \\
\hline 2 & Incidence & 2 & $0-2$ & $\begin{array}{l}1.2 \\
7\end{array}$ & 63.50 & 0.71 \\
\hline 3 & Causes & 6 & $0-5$ & 2.7 & 45 & 1.31 \\
\hline 4 & $\begin{array}{l}\text { Clinical } \\
\text { features }\end{array}$ & 2 & $0-9$ & $\begin{array}{l}4.2 \\
3\end{array}$ & 35.25 & 2.05 \\
\hline 5 & Diagnosis & 2 & $0-2$ & 1.7 & 85 & 0.49 \\
\hline 6 & Management & 9 & $2-9$ & $\begin{array}{l}6.9 \\
5\end{array}$ & 77.22 & 1.75 \\
\hline
\end{tabular}

Table 5 shows that mean score percentage for knowledge regarding Diagnosis and management of learning disability were high $(85 \%$ and77.22\%respectively). They were 
found to have the least knowledge $(35.25 \%)$ on idea regarding clinical features. Other areas like Meaning Causes, Incidence and causes carried $38.33,63.5$ and $45 \%$ respectively.

\section{SECTION V}

\section{LEVEL OF ATTITUDE OF THE SUBJECTS}

Teachers were divided into three groups based on the attitude score. Those who scored above $75 \%$ was considered as having highly favorable attitude, $75-50 \%$ as favorable and below $50 \%$ as unfavorable attitude.

Table 6 Frequency and Percentage distribution of subjects according to the Attitude score on Learning Disability

Highly favorable Attitude - >75\%

FavorableAttitude-75-50\%

Unfavorable Attitude $-<50 \%$

\begin{tabular}{|l|l|l|l|l|l|l|}
\hline $\begin{array}{l}\text { S. } \\
\text { No }\end{array}$ & $\begin{array}{l}\text { Level of } \\
\text { knowledge }\end{array}$ & $\begin{array}{l}\text { Freque } \\
\text { ncy }\end{array}$ & $\begin{array}{l}\text { Percentage } \\
(\%)\end{array}$ & $\begin{array}{l}\text { Me } \\
\text { an } \\
\text { scor } \\
\text { e }\end{array}$ & $\begin{array}{l}\text { Mean } \\
\text { percentag } \\
\text { e } \\
\text { Score(\%) }\end{array}$ & SD \\
\hline 1 & $\begin{array}{l}\text { Highly } \\
\text { favorab } \\
\text { le } \\
\text { attitude }\end{array}$ & 118 & 98.33 & 80.71 & 89.6 & 6.61 \\
\hline 2 & $\begin{array}{l}\text { Favorable } \\
\text { attitude }\end{array}$ & 2 & 1.67 & 68 & 75.55 & 0 \\
\hline 3 & $\begin{array}{l}\text { Un } \\
\text { favorab } \\
\text { le } \\
\text { attitude }\end{array}$ & 0 & 0 & 0 & 0 & 0 \\
\hline
\end{tabular}

Table 6shows that out of 120 samples 118 (98.33\%) had Highly favorable attitude towards problem children. Only 2
$(1.67 \%)$ in Favorable level and none in Unfavorable attitude level. Mean score for highly favorable attitude was 80.71 and mean percentage score $89.6 \%$ with a $\mathrm{SD}$ of 6.61.For favorable attitude, mean score was 68 and mean percentage score $75.55 \%$.

\section{SECTION VI: CORRELATION BETWEEN KNOWLEDGE AND ATTITUDE}

In the section VI, correlation between knowledge and attitude of teachers towards learning disability is analyzed using Karl Pearson's Correlation Coefficient. From that value Test of significance was done to estimate the level of significance.

Table 7 Mean and Correlation between Knowledge and Attitude score of teachers regarding learning disability

\begin{tabular}{|c|c|c|c|}
\hline Particulars & Mean & SD & $\begin{array}{c}\text { Coefficient of } \\
\text { Correlation }\end{array}$ \\
\hline Knowledge & 21.08 & 5.93 & +0.833 \\
Attitude & 80.5 & 6.59 & \\
\hline
\end{tabular}

Table7 shows that there is positive correlation between knowledge of teachers regarding learning disability and their attitude towards such children. Correlation Coefficient is found to be +0.833 with test of significance 6.3 .

Hence $\mathrm{H} 3$ is accepted at $\mathrm{P}<0.05$. 


\section{CONCLUSION}

The study was a Descriptive type to assess the knowledge and attitude of school teachers regarding learning disability among children in selected schools at Churu District. Analysis was done and the following conclusions were drawn.

$>$ Majority of the primary school teachers had inadequate knowledge on learning disability.

$>$ Most of the subjects possessed highly favorable attitude towards learning disabled children.

$>$ Educational qualification of teachers and their knowledge regarding learning disability was found to be significantly associated. Other socio demographic variables had no significant association with knowledge of teachers on learning disability.

$>$ Age of the teachers had significant association with attitude. Other socio demographic factors have no significant association with attitude of the teachers.

$>$ There is significant positive correlation between knowledge and attitude of teachers on learning disability.

\section{BIBLIOGRAPHY}

1. Neeraja KP. Text Book of Nursing Education. 1st ed. New Delhi (India): Jaypee Brothers Medical Publishers (P)LTD;2003.

2. Esther SS . A Study to determine the effectiveness of teaching strategies for primary school teachers on selected health problems among school children in AnekalTaluke, Karnataka State, Rajiv Gandhi University, Bangalore, India;1998.

3. Mony EH. A Study to assess the knowledge and to evaluate the effectiveness of planned teaching programme on Attention Deficit Hyperactivity Disorder for school teachers in selected rural area, Namakal District, Tamilnadu;2003.

4. American Psychiatric Association. DSM-IVTM. $\quad 4^{\mathrm{TH}}$ ed. New Delhi(India):Jaypee

Publishers;2000.

5. Garnett K. Students with Learning Disability.(120034)

November1998(Cited2005

July20);33(2): ( 200-03)available from http://ctl.unl edu/tfi14.html. 